\title{
今日の話題
}

\section{細胞培養マイクロデバイスの研究 マイクロスケールでの細胞培養・解析技術}

フォトリソグラフィと呼ばれる光を用いた微細加工技 術が，主に半導体産業で発展してきた.ナノメートル オーダーの精度で微小な電極配線や構造体を作製でき, 身近にあるさまざまな工業製品に用いられている，PC やデジタルカメラ，スマートフォンなどが飛躍的に高性 能化, 小型化した主な理由の一つがこの微細加工技術の 進歩である。10年ほど前から，この技術をウェットな 系であるバイオ分野へ応用し，全く新しい解析技術を開 発する試みが活発になってきた。この領域は, Lab on a chip Picrofluidics, BioMEMSなどさまざまな名称で 呼ばれ，関連するジャーナルや学会が設立されている.

安価な研究室用の装置でも, 細胞や微生物と同等以下 のスケールで微細加工ができるため, たとえば細胞の周 囲の環境を正確にコントロールして, 従来の培養方法で は不可能な特殊な培養条件下で細胞の応答を解析するよ うなマイクロデバイスも開発されている.このような新 しい細胞培養法は，細胞システムをより詳細に解析する 基礎的な分野から, 再生医療のような応用分野に適用さ れ，さまざまな展開が図られている。ここでは，いくつ かの細胞培養マイクロデバイスについて紹介したい.

生体内の細胞は, 周囲の液性因子（成長因子や酸素, 栄養素など）によって機能や増殖などが制御されている が，単に液性因子の濃度を感知するだけではなく，その 濃度勾配も認識して遊走する方向や突起を伸ばす方向な
どが決定されている。このような機能は，発生の過程で 組織や臓器が形成される際や, 微生物が自らにとってよ り好ましい方向へ移動する際にも重要な役割を果たして いる．細胞のもつこのような性質を詳細に調べるため に, 微小な流路を分岐・蛇行させ濃度勾配を作り出すこ とができるマイクロデバイスが開発されている ${ }^{(2)}$. 図 1 は，このような濃度勾配形成と細胞試験が可能なマイク ロデバイスであり, 濃度勾配を可視化するために, Inlet 1 と Inlet 2 から赤と緑の蛍光基質溶液を送液した様子で ある. 中央の分岐・蛇行構造によって一連の混合比系列 の溶液が作り出され，これらを再び1本の Main channel で合流させることで，流れに垂直な方向に濃度勾配が形 成される (図 $1 \mathrm{C}, \mathrm{D})$. このデバイスを用いて，たとえ ば神経成長因子の濃度勾配下における神経突起の伸長の 様子などが評価されている.

図1のマイクロデバイスは，さらにInlet 3 と Inlet 4 を用いることで, Main channel内の特定の位置のみに 細胞を接着させることができるように工夫されている. つまり，従来は濃度勾配下での細胞の動きを評価するに は, Main channelを連続的に観察して細胞を追跡する 必要があったが，このマイクロデバイスでは，培養開始 時の細胞の位置を決めてやることで，培養後に観察する だけで濃度勾配に対して細胞がどの程度移動したのかが わかるというものである。細胞をマイクロ流路内の特定

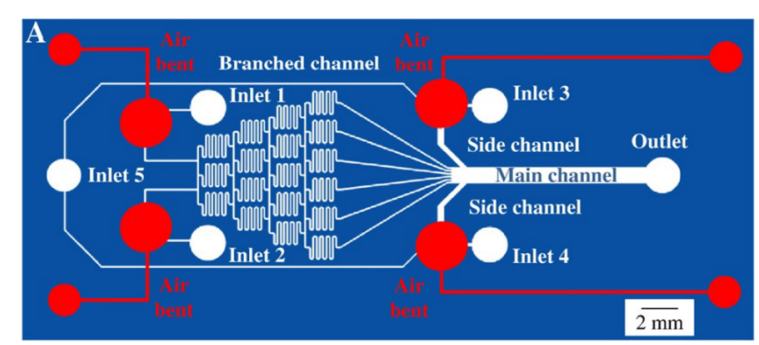

\section{B}

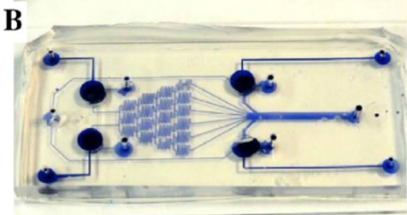

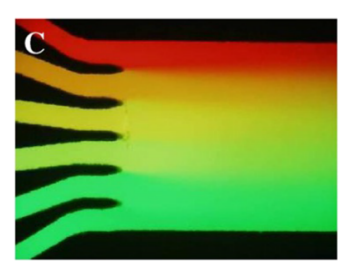
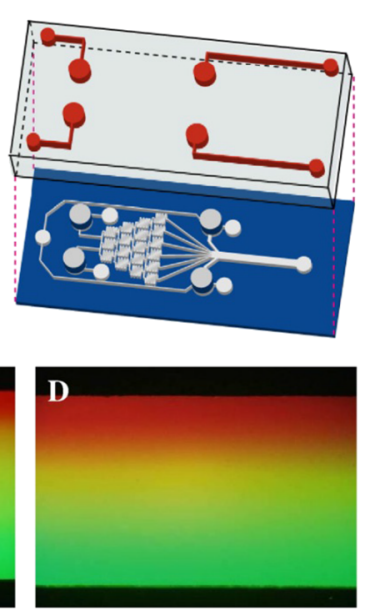


\section{今日の話題}

の位置のみに接着させる方法についてはここでは詳しく 説明しないが，後述するように細胞と同等スケールで細 胞接着性をダイナミックにスイッチングする技術もまた この領域ならではのアプローチである.

微細加工技術を用いて生体内の組織類似構造を作製 し, 創薬や再生医療に役立てようという研究も進められ ている，たとえば，Ingberらは，肺胞組織を再現する マイクロデバイスを開発した ${ }^{(3)}$ 。このデバイスでは，厚 み $10 \mu \mathrm{m}$ のシリコーンゴムシートに直径 $10 \mu \mathrm{m}$ の貫通孔 を複数あけ，そのシートを介して上面と下面に肺胞上皮 細胞と血管内皮細胞を接着させた，そして，このシート を呼吸と同じようなリズムで伸縮させることで生体の肺 と同じような力学的な刺激を付与した。このように呼吸 の状況を模倣することで初めて，生体の肺と同じナノ粒 子の取り込み挙動が観察されたと報告している。彼らは また，腸の蠕動運動を模倣した波状の力学刺激を与える ことで，通常の培養血での培養では形成されない絨毛が 形成されることも見いだした。そして，蠕動を与えて培 養した場合に，ヒト腸細胞と腸内細菌が共存できること も示した ${ }^{(4)}$ 。このような, 生体外で臟器や組織の挙動を 解析できるデバイスは，特にOrgan on a chip とも呼ば れている.肝臓，血管，筋肉などの開発も進められてお り，創薬における動物実験代替としても期待されてい る.

紹介する最後の例は，微小な電極配線と電気化学反応 を用いて任意の細胞のみを脱離・回収するマイクロデバ イスである，スマートフォンやノートPCなどに用いら れる液晶デイスプレイには，透明な電極材料が細かく配 線されており, 特定のピクセルに電圧を印加して光を変 調することで全体として画像を表示している，電極配線 の細かさがディスプレイの解像度を決める大きな要因と なるため，その微細加工技術はかなり高度に制御できる ようになっている，一方，電極の表面に密な分子層を形 成し，これを介して電極表面に結合したタンパク質や細 胞を，この分子層を電気化学的に切断することで，一緒 に脱離させる方法が報告されている( ${ }^{(5)}$ (図2)，分子層に は，アルカンチオールと呼ばれる分子がよく用いられて

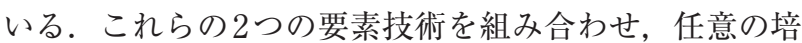
養細胞一つを脱離させて回収するマイクロデバイスが報 告されている，つまり，従来は顕微鏡下で培養血の表面 に接着したそれぞれの細胞を観察することができても， そこに見えているある特徵的な細胞のみを培養系から回

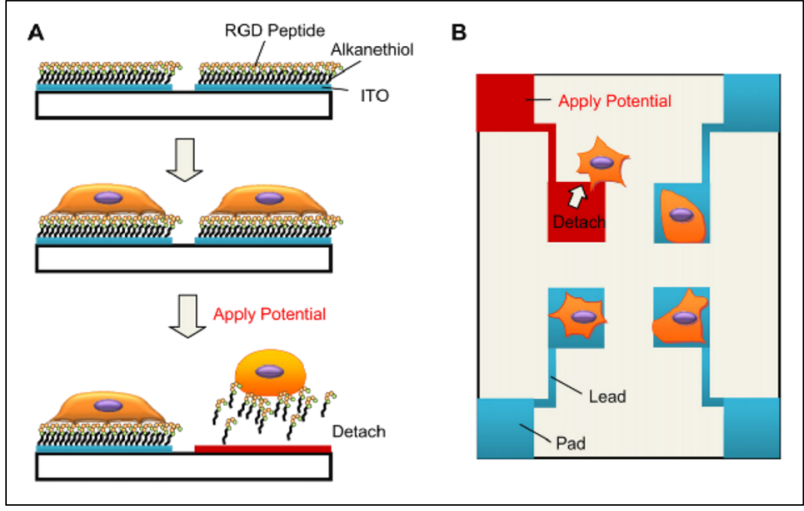

図 2 a 特定の細胞のみを回収するマイクロデバイス ${ }^{(5)}$

A. 電気化学細胞脱離の原理，B．アレイ電極， RGD：アルギニ ンーグリシンーアスパラギン酸, ITO：酸化インジゥムスズ

収したり，または逆に排除したりすることは難しかっ た。しかし，このデバイスを用いると細胞一つのみを ピックアップしたり，一つの細胞の接着領域の半分のみ を脱離させることなどが可能である.

フォトリソグラフィなどの微細加工技術が動物細胞や 微生物の培養に用いられてきている。これらのマイクロ デバイスでは，従来のマクロな系では設定不可能であっ た条件下で細胞を培養・解析できるため，これまで知ら れていなかった細胞の性質の発見にもつながる。またこ こでは紹介しなかったが，必要なサンプル量を極端に低 減できるため，培養系のみならず，化学・生物サンプル などの分析にも用いられている，今後，このようなマイ クロデバイス技術がさらに発展すればLab on a chipの 概念そのものである,「研究室の機器が切手程度のチッ プ上にすべて集積化される」という日が来るかもしれな い.

1) T. Okuyama, H. Yamazoe, Y. Seto, H. Suzuki \& J. Fukuda:J. Biosci. Bioeng., 110, 230 (2010).

2) S. K. W. Dertinger, D. T. Chiu, N. L. Jeon \& G. M. Whitesides: Analytical Chem., 73, 1240 (2001).

3) D. Huh, B. D. Matthews, A. Mammoto, M. Montoya-Zavala, H. Y. Hsin \& D. E. Ingber: Science, 328, 1662 (2010).

4) H. J. Kim, D. Huh, G. Hamilton \& D. E. Ingber:Lab. Chip, 12, 2165 (2012).

5) J. Fukuda, Y. Kameoka \& H. Suzuki: Biomaterials, 32, 6663 (2011).

$($ 福田淳二 $* 1$, 掛川貴弘 $* 2, * 1$ 横浜国立大学工学研究 院, $* 2$ 筑波大学数理物質科学研究科) 


\section{今日の話題}

プロフィル

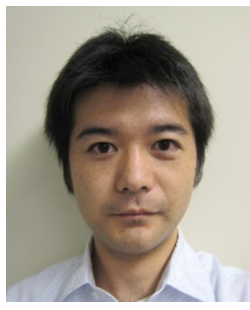

福田 淳二 (Junji FUKUDA) <略歴> 1998年九州大学工学部化学機械工学科卒 業 / 2000 年同大学大学院修士課程修了/ 2003 年同大学大学院博士後期課程修了, 博士 (工学) / 2003 年知的クラスター創成 事業招聘研究員 (北九州市立大学) $/ 2004$ 年日本学術振興会特別研究員 (PD) (北九 州市立大学) / 2005年 MIT, Robert Langer lab, Postdoctoral Fellow（MIT) /2006年 筑波大学大学院講師 $/ 2013$ 年横浜国立大 学大学院准教授, 現在に至る<研究テーマ と抱負 $>$ 血管構造を有する立体的な臟器・ 組織の構築＜趣味＞マラソン, スノーボー ド

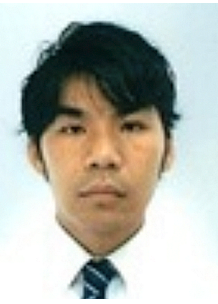

掛川 貴弘 (Takahiro KAKEGAWA) <略歴>2010年筑波大学第三学群工学 基礎学類卒業 / 2012 年同大学大学院博士 前期課程修了/同年同大学大学院博士後 期課程/同年日本学術振興会特別研究員 (DC1) (筑波大学) <研究テーマと抱負> 電気化学的手法による再生医療技術の確立 <趣味>読書, サッカー 